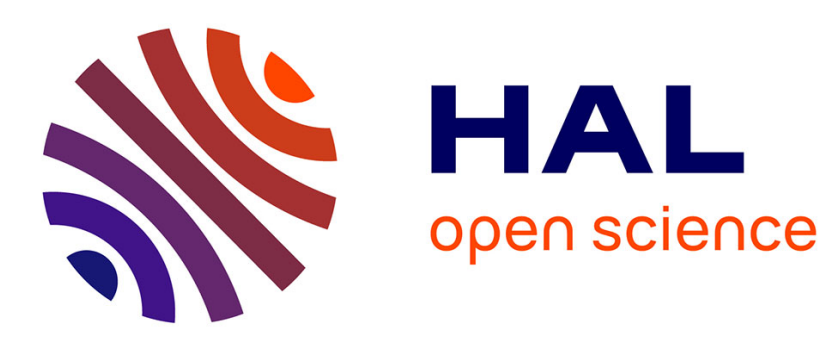

\title{
Pulse-Magnetic Processing Technology when Making Parts and Units of Aerospace Engineering
}

\author{
V. Glouschenkov, F. Grechnikov, B. Malyshev
}

\section{To cite this version:}

V. Glouschenkov, F. Grechnikov, B. Malyshev. Pulse-Magnetic Processing Technology when Making Parts and Units of Aerospace Engineering. Journal de Physique IV Proceedings, 1997, 07 (C3), pp.C3-45-C3-48. 10.1051/jp4:1997310 . jpa-00255383

\section{HAL Id: jpa-00255383 https://hal.science/jpa-00255383}

Submitted on 1 Jan 1997

HAL is a multi-disciplinary open access archive for the deposit and dissemination of scientific research documents, whether they are published or not. The documents may come from teaching and research institutions in France or abroad, or from public or private research centers.
L'archive ouverte pluridisciplinaire HAL, est destinée au dépôt et à la diffusion de documents scientifiques de niveau recherche, publiés ou non, émanant des établissements d'enseignement et de recherche français ou étrangers, des laboratoires publics ou privés. 


\title{
Pulse-Magnetic Processing Technology when Making Parts and Units of Aerospace Engineering
}

\author{
V.A. Glouschenkov, F.V. Grechnikov and B.S. Malyshev \\ Samara State Aerospace University, Kumertau Aircraft Industrial Enterprize, 34 Moskovskoye shosse, \\ Samara, Russia
}

\begin{abstract}
Experience on using of pulse-magnetic processing of materials (PMPM) at the enterprises of the aero-space industry is presented. The emphasis is on the processes of hollow billets stamping. A complete list of technological processes mastered is available, advantages of these processes are outlined. The paper is illustrated with some examples of the concrete parts and units made with a help of the pulse-magnetic technology.

Resume. On décrit l'expérience de l'utilisation du formage inagnétique dans les entreprises de l'industrie aérospatiale. On parle surtout des processus du formage des piéces brutes creuses. On procéde á l'énumération de tous les processus mis en oeuvre, on décrit leurs avantages. Il y a quelques exemples de piéces et de sons-ensembles concrets fabriqués á l'aide de la technique magnétique.
\end{abstract}

Pulse-magnetic processing of materials (PMPM) has found the widest application at the enterprises of the aerospace industry of the former Soviet Union. 36 specialized production sectors have been organized at the enterprises in cities of Samara, Mos-cow, Smolensk, Novosibirsk, Kiev, Kharkov, Nizhni-Novgorod, Kazan, Voronezh and other, where 49 pulse-magnetic setups are operating. Industrial production of 4230 names of parts and units of air-crafts and engines has been mastered The parts and units made with this method are used successfully in constructions of planes (model Ту, Як, Ан) and of spacecrafts ( model Vostok, Soyuz, Energya, Progress).

From a list of parts and units been mastered the emphasis was on processing of seamless and welded hollow billets: pipes, cylind-rical and conic shells, shells of other, more complex configura-tions. They are primarily parts of different pipe systems (fuel, anti-icing, conditioning, power supplying, supercharge thermal stabilization and other systems) as well elements of the power set (pulls, side slopes, frames, molds ...). From hollow billets the shells of various kinds are made: deflectors, parts of com-bustion chambers, suspension containers, elements of rocket wea-pon, to name but a few

Attention to pulse-magnetic processing of materials is dictated by the fact that when using traditionai technologies for making of hollow parts their quality does not match the increased requirements of production. As a consequence, for example, an operating life of a pipeline on the average is smaller than an operating life of a glider by a factor of 2 and in consumable objects up to 90 percent of a number of crashes happen because of depressurization of the pipelines. Besides that the higher atten-tion to pulse-magnetic processing of hollow billets is caused by the economic efficiency of production: economizing on metal, rai-sing of labour productivity. In specific cases pulse-magnetic processing is intriguing by provising of new technical possibili-ties, for example, by providing of a possibility of assembly of carbon-plastic pipes with metal tips.

To proceduce from hollow billets parts and units of aircrafts and engines the package of separating, shaping, calibrating, assemb-ling and combined operations of pulse-magnetic deforming has been developed. Fig. 1. $[1,2]$

- Separating operations. 1. Cutting of pipes into measuring lengths when a cur line is normal, inclined or figured relative to the billet axis. This operation is both an individual operation 
TECHNOLOGICAL PROCESSES MAGNETIC PULSE MANUFACTURE OF PIPE BILLETS

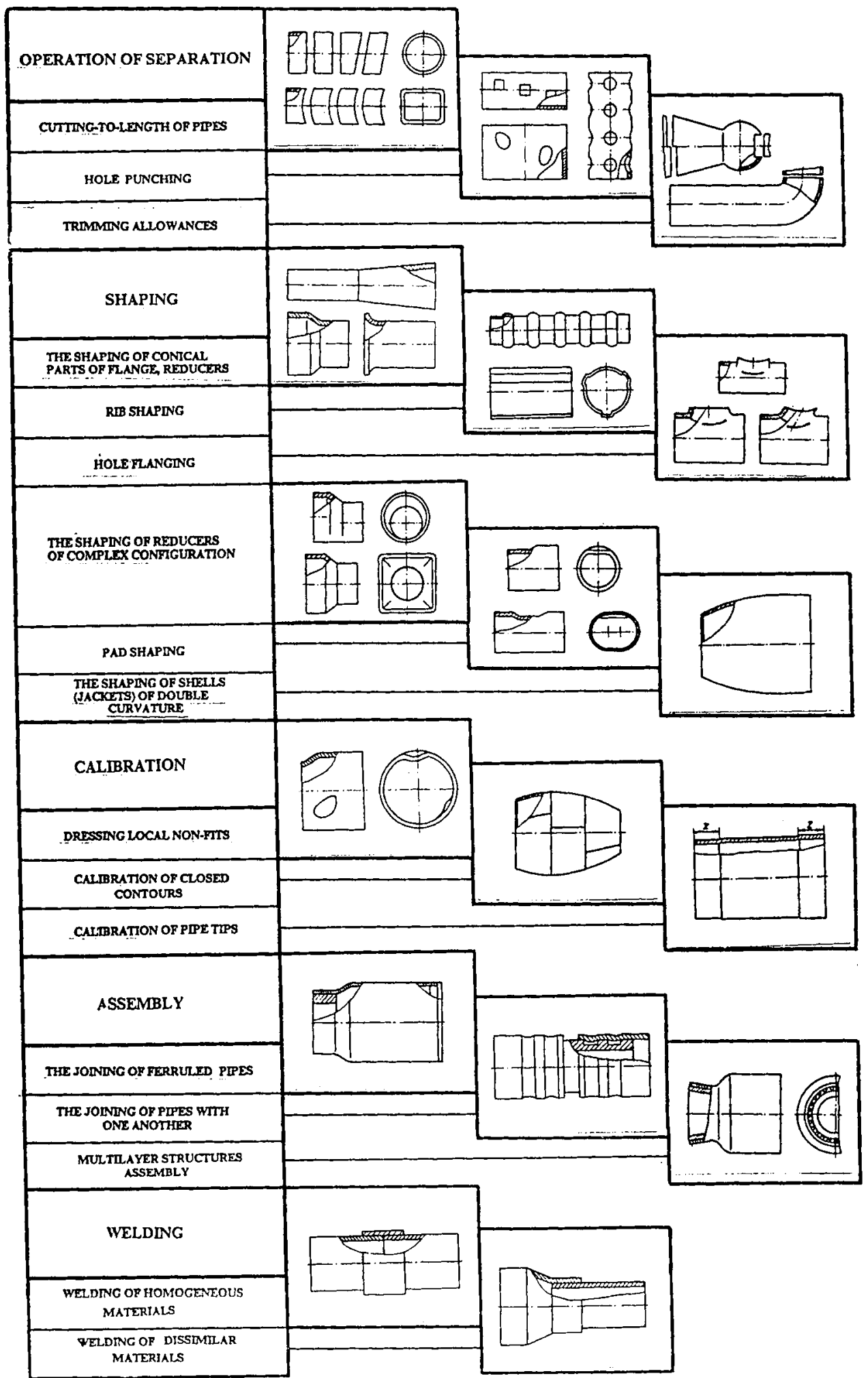


when making elements of a pipeline and an intermediate one when with a help of this operation the billets are produced for following processing, e.g., for shaping. 2. Trimming of an allowance of hollow parts with variously shaped cut lines. Trimming of the allowance is carried out on faces of rectilinear seamless or welded pipes, on hollow parts of various shapes: sharp bent sleeves, extended buckets, boxes, housings, shells and so on. 3. Unit or group piercing of holes of circular, rectangular, oval and other configuration at a side surface of hollow parts. In all these cases simultaneously with cutting the calibration of the sections adjacent to the separation surface is carried out.

- Shaping operations. 1. Uniform all along the entire generatrix expansion or squeezing of short pipes and cylindrical shells, successive deforming with overlapping of molded and unmolded sections when producing long-sized off-dimension pipes. 2. One-pass and multi-pass processes of deforming of a cones, reducers, flanges, longitudinal and transverse ridges (grooves) including at ends of long-sized products. 3 . Beading of holes on pipes and hollow parts of various configurations. 4. Producing of complex-shaped parts: reducers with a displacement of the longitudinal axis or with changes of a cross-section shape (circle-oval, circle-square ...), molding of platforms for accomodation and fastening of different sensors. 5. By-element molding of double-curvature shells using a specific sectional inductor with a programmer change-over of the sections.

- Calibrating operations. 1. Calibration of ends of hollow parts for soldering, welding or assembly. 2. Calibration of the counter of the entire detail entering, for example, an aerodynamic stream. 3. Dressing of local non-fits: peaks and valleys of various types.

- Assembling operations. 1. Assembly of tubular elements with tips. Assembly is carried out both at expense of producing of a pull between connectable pieces with no change of their shape and at expense of geometric closure-shaping of a pipe (grooves, cones, flanges.). For assembling of metal tips with carbon-plastic pipes the technology of deforming them in the partially polymerized conditon was used. 2 . Assembly of hollow parts with one another. Therewith the technology of simultaneous deforming of multilayer constructions has been realized. 3. Fastenning (setting) of protective coverings, hoses, thickening bushes and other nonmetal elements. Some assembling operations may be changed for pulse-magnetic assembly as the need arose.

- Combined operations. For producing of hollow parts the technologies are proposed which combine several operations at a time: molding and trimming of an allowance, piercing of holes and calibration, assembly and molding and so on.

The main advantages of the PMPM processes developed are: ecological cleanliness, short computer time assuring high productivity of the processes, new technological potentialities, an increase in limiting possibilities of the processes and as a result - a decrease in a number of passes, upgrading of finished production, shortening of a weld seam length, an increase of joint durability, simplification of constructions and lowering of metal consumption of technological equipment.

The development of PMPM technological processes was preceeded by fundamental and applied research on processes of pulse deforming of cylindrical billets:

- the investigation of kinematics of billet movement under loading of different types and various boundary conditions [3];

- the determination of heat effects and their function in the PMPM processes [4];

- the investigation of mechanic properties of materials under pulse-magnetic loading ;

- the analysis on a mechanism for separation, on the applicability of different criteria for separation under pulse loading [5];

- the investigation of influence of a cylindrical billet-equipment collision on finished products quality [6].

The research conducted has served as a basis for developing of the effective industrial technologies for making of a lot of parts and units of aircrafts and engines as exemplified below: 
1. Double-curvature shells The principle of the technological process developed is expansion of separate parts of a conical billet with a help of the multisection inductor whose shape and size are appropriate to the last pass - to calibration of the part. Shaping of the part and its calibration are conducted at one setting. Making of shells from the alloy $\mathrm{AMr}$ up to $1000 \mathrm{~mm}$ in diameter and in height and up to $3 \mathrm{~mm}$ in wall thickness has been mastered. Dies for stamping are of laminated-wood plastic. The inductors have from 2 to 12 sections, work of which is remotely controlled under a specified program through a hydromechanical commutator. Introduction of the pulse-magnetic technology has allowed to increase labour productivity by 3-4 times and when manual finishing is ruled out and 9-11 quality is provided - to reduce withdrawal of metal by $25-30$ percent and to decrease metal consumption of equipment withhout lowering of its stability.

2. Steering and sustainer liquid-propellant rocket engines. The pulse-magnetic technology allows to press a copper ribbed cooling jacket in a steel carcass all along the entire generatrix before soldering. The strictly dosed energy ensures intimate mating of ribs to the carcass surface in their true sizes, move-ments of the carcass therewith are not beyond the limits of elastic deformation. The introducting of this technology has totally obviated conceivable rejects «for unsoldering».

3. Frames and trusses made of carbon-plastic pipes. The requirement of weight lessening especially in aviation and space rocketary constructions brings about a wide application of composite materials and carbon-plastics among them. The problem of joining carbon-plastic pipes with metal componets as used here is the most pressing problem. Mechanical spot joints are not effective (because fibers are damaged when drilling holes for bolts and riverts) and welding is impossible. The application of pulse-magnetic assembly is suggested as a possible way out. The first version is to clamp up a carbon-plastic pipe between aluminium (metal) elements to be deformed. The second version is the simultaneous deformation of a carbon-plastic pipe with metal elements creating a counter closure. The deformation of a carbon-plastic pipe is made possible when carring out the previous partial polymerization of the pipe. The carbon-plastic pipe is heated up to $120-130^{\circ} \mathrm{C}$ to make it elastic.

\section{Conclusion}

The package of the effective technological processes of pulse-magnetic processing of hollow billets, in common use primarily at the enterprises of the aerospace industry, has been developed.

\section{References}

[1] Glushchenkov V.A. Analysis of method of thin walled pipe cutting in specified lengths. ICMF'91, Gyor, Hungary, 1991

[2] Глущенков В.А. Основные направления развития магнитно-импульсной обработки. Кузнечно-штамповочное производство. 1990, N7

[3] Glouschenkov V.A. High-specd filming technique in investigation billet deformation kinematics. ISIE, Japan, 1992

[4] Glouschnekov V.A. The role of thermal Effects in the productions of parts and inits by means of pulse magnetic ficld. Thermal Stresses' 95 . Japan, 1995

[5] Kislooky V.N. The progress of zone of destruction in the time of magnetic-impulse cutting of tubes. ICF-8, Kiev, 1993

|6| Глущенков В.А., Комаров А.Д., Щеглов Б.А. Упругое соударение цилиндрической заготовки с матрицей при магнитно-импульсной обработке металлов.

Машниоведение, 1972, N 3. 